Prepared for the U.S. Department of Energy

under Contract DE-AC05-76RL01830

\title{
Determination for the 2006 International Energy Conservation Code, Residential Buildings - Technical Support Document
}

RG Lucas

September 2009

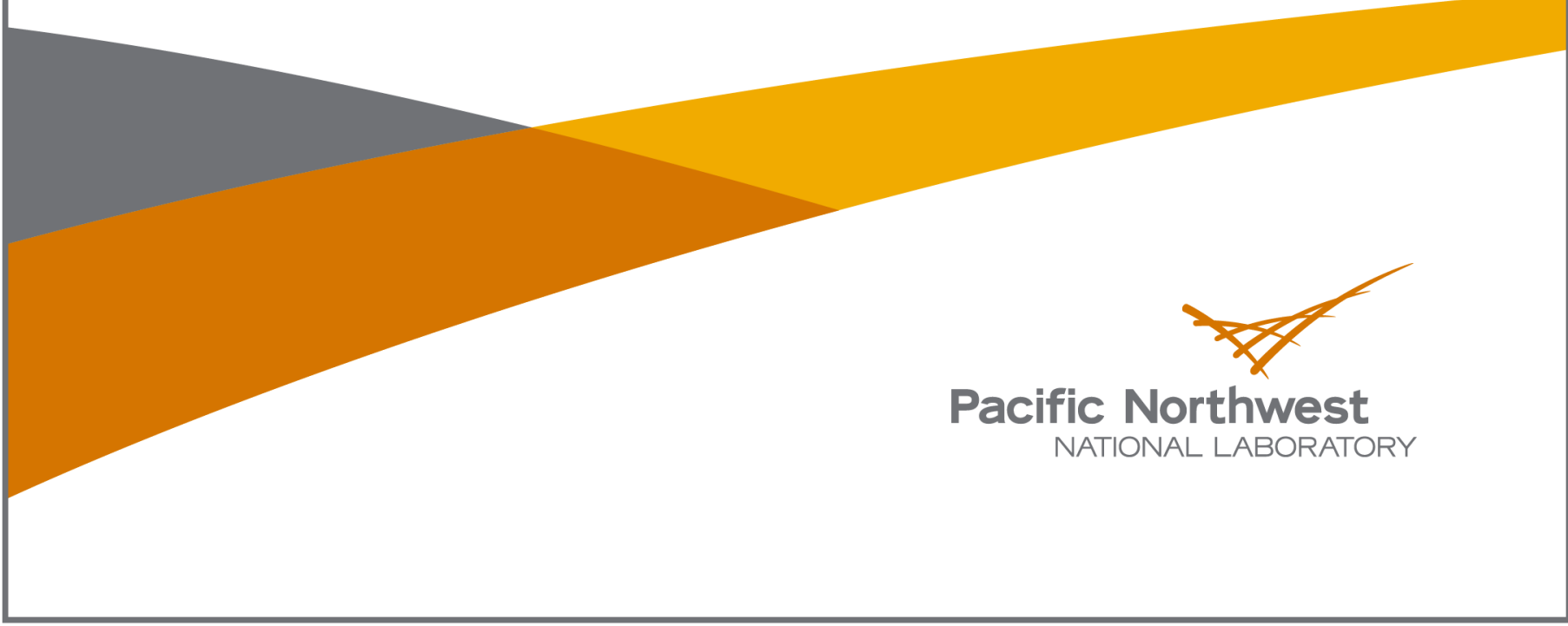




\title{
DISCLAIMER
}

United States Government. Neither the United States Government nor any agency thereof, nor Battelle Memorial Institute, nor any of their employees, makes any warranty, express or implied, or assumes any legal liability or responsibility for the accuracy, completeness, or usefulness of any information, apparatus, product, or process disclosed, or represents that its use would not infringe privately owned rights. Reference herein to any specific commercial product, process, or service by trade name, trademark, manufacturer, or otherwise does not necessarily constitute or imply its endorsement, recommendation, or favoring by the United States Government or any agency thereof, or Battelle Memorial Institute. The views and opinions of authors expressed herein do not necessarily state or reflect those of the United States Government or any agency thereof.

\author{
PACIFIC NORTHWEST NATIONAL LABORATORY \\ operated by \\ BATTELLE \\ for the \\ UNITED STATES DEPARTMENT OF ENERGY \\ under Contract DE-AC05-76RL01830 \\ Printed in the United States of America \\ Available to DOE and DOE contractors from the \\ Office of Scientific and Technical Information, \\ P.O. Box 62, Oak Ridge, TN 37831-0062; \\ ph: (865) 576-8401, fax: (865) 576-5728 \\ email: reports@adonis.osti.gov \\ Available to the public from the National Technical Information Service, \\ U.S. Department of Commerce, 5285 Port Royal Rd., Springfield, VA 22161 \\ ph: (800) 553-6847, fax: (703) 605-6900 \\ email: orders@ntis.fedworld.gov \\ online ordering: http://www.ntis.gov/ordering.htm
}

This document was printed on recycled paper. 
PNNL-18806

Determination for the 2006 International Energy

Conservation Code, Residential Buildings Technical Support Document

RG Lucas

September 2009

Prepared for

U.S. Department of Energy

under Contract DE-AC05-76RL01830

Pacific Northwest National Laboratory

Richland, Washington 99352 


\section{Summary}

The Energy Conservation and Production Act (Pub. L. 94-385) as amended, requires the U.S. Department of Energy (DOE) to determine whether revisions to the International Energy Conservation Code (IECC) (ICC 2006) would improve energy efficiency in residential buildings. An "affirmative determination" for any IECC revision triggers a requirement that each state certify to DOE, within 2 years of the publication of the determination, that it has reviewed the provisions of the new code and made a determination whether it is appropriate to update its building code(s) to meet or exceed the revised IECC.

In January 2006, the International Code Council (ICC) published its 2006 edition of the IECC. This report documents an analysis of the impacts on energy efficiency of the differences between the 2003 and 2006 editions of the IECC. The residential provisions of the IECC were completely restructured in the 2006 edition, resulting in a code that is much shorter and simpler than its 2006 predecessor. The most significant changes resulted from a proposal by DOE that was primarily intended to improve the IECC's usability rather than its efficiency. However, the format differences do impact efficiency in some ways, and there were substantial changes to multifamily requirements.

The major differences between the 2003 and 2006 editions of the IECC are:

- A change in the climate basis for requirements

- A consolidation of single- and multifamily requirements (the 2003 IECC has separate, less stringent requirements for multifamily buildings)

- A decoupling of envelope efficiency requirements from window to wall area ratio (WWR)

- The elimination of some compliance paths

- A completely rewritten Simulated Performance Alternative compliance path

DOE's analysis concludes that, averaging across building types, foundation types, and locations, the 2006 IECC does improve energy efficiency in residential buildings. Because of the extensive format differences, there are considerable variations in relative efficiency between various building types, locations, house designs, and even compliance paths, but overall the 2006 IECC is an improvement compared to its 2003 predecessor. 


\section{Contents}

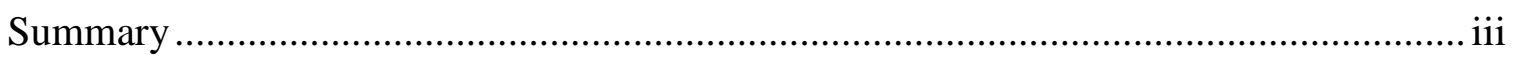

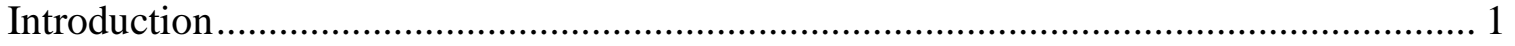

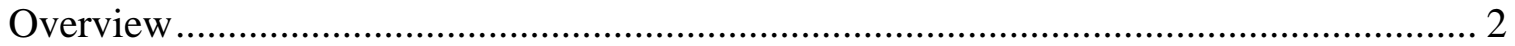

Simulation Analysis of Prescriptive Thermal Envelope Measures...................................... 4

Methodology and Assumptions …………………….......................................... 4

Thermal Envelope Measures in the IECC ………..................................................... 4

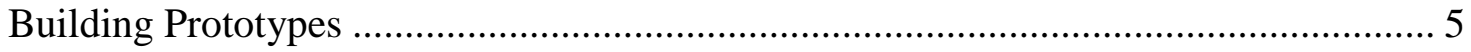

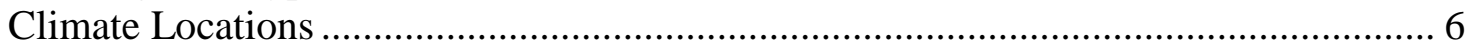

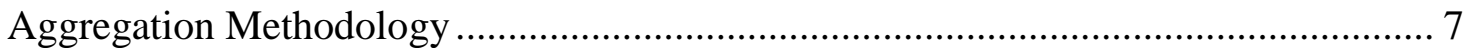

Combining Across TMY2 Locations Within Climate Zones …………………... 7

Climate Zone Shares..................................................................................... 8

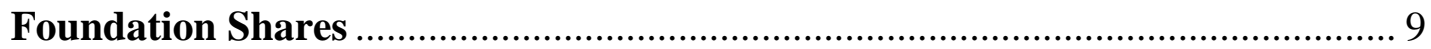

Single-Family and Multifamily Shares …………....................................... 10

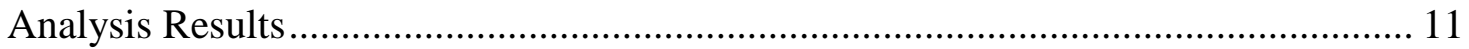

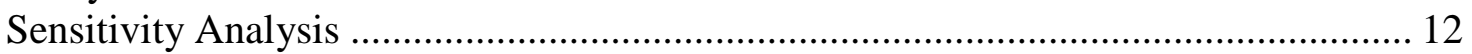

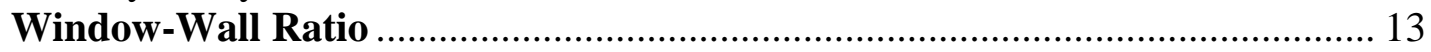

Sensitivity to Other Assumptions ............................................................... 14

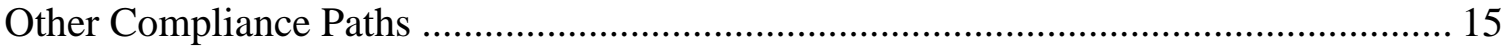

Compliance by U-Factor ....................................................................................... 15

Performance Approach ........................................................................................ 16

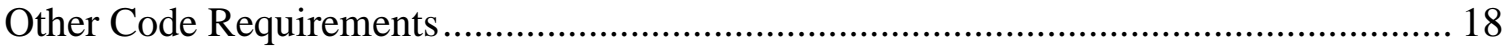

Mechanical System Requirements .................................................................... 18

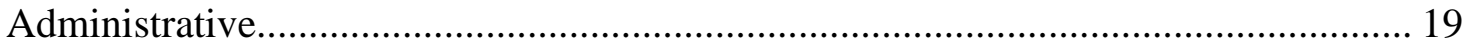

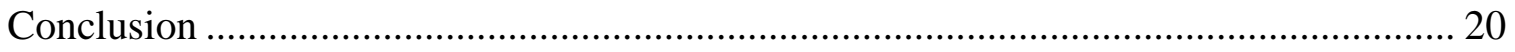

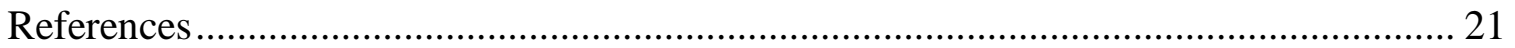

Appendix - Elimination of Window Area Dependencies ............................................... 24

Is the 2006 IECC less stringent than the 2003 IECC because of its leniency with

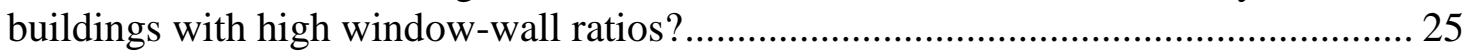

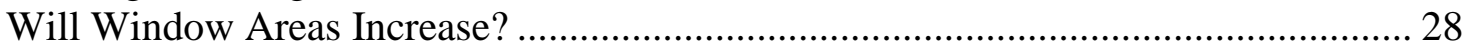

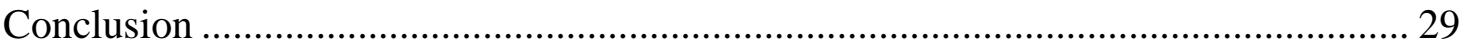




\section{FIGURES}

Figure 1. 239 Locations Analyzed and the Climate Zones of the 2006 IECC................. 7

Figure A- 1. Window Area Percentages in New Residential Buildings ........................ 26

\section{TABLES}

Table 1. Single-Family Prototype Characteristics ….............................................. 5

Table 2. Housing Start Shares by Climate Zone ........................................................ 8

Table 3. Percentage of Locations in Each 2006 IECC Climate Zone that Would Have Been in Each 2003 IECC Climate Zone. ..................................................................... 9

Table 4. Foundation Type Shares (percent) by Census Zone ....................................... 10

Table 5. Foundation Type Shares (percent) by 2006 IECC Climate Zone ..................... 10

Table 6. Annual Energy Savings (MBtu) of 2006 IECC Compared to 2003 IECC -

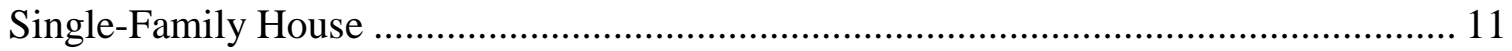

Table 7. Annual Energy Savings (MBtu) of 2006 IECC Compared to 2003 IECC -

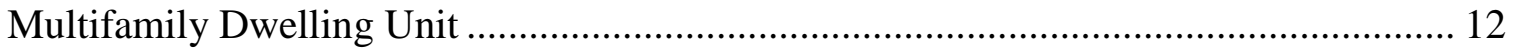

Table 8. Annual Energy Savings (MBtu) of 2006 IECC Compared to 2003 IECC Combined Single-Family and Multifamily .............................................................. 12

Table 9. Annual Energy Savings (MBtu) of 2006 IECC Compared to 2003 IECC Single-Family House .................................................................................... 13 Table 10 Improvement in Whole Building Thermal Transmittance ("UA", percent) in the 2006 IECC - Single-Family House 16

Table A- 1. Window-Wall Ratios (percent) At Which 2003 IECC and 2006 IECC Have Equivalent Gross Wall Requirements (Single-Family) .............................................. 27 


\section{Introduction}

The Energy Conservation and Production Act (Pub. L. 94-385) as amended requires the U.S. Department of Energy (DOE) to determine whether revisions to the International Energy Conservation Code (IECC) (ICC 2006) would improve energy efficiency in residential buildings. In January 2006, a new edition of the IECC was issued.

This document evaluates the differences in energy efficiency between the 2006 IECC and its predecessor, the 2003 IECC, for residential buildings. 


\section{Overview}

The 2006 IECC differs extensively from the 2003 IECC. The residential provisions of the IECC were completely restructured, resulting in a code that is much shorter and simpler. The residential-specific portion of the 2003 IECC comprises three chapters with a total length of 38 pages. In the 2006 IECC, this had been reduced to one chapter and nine pages. Additionally, the 2003 IECC's 50 state/county climatic maps, which apply primarily to commercial buildings but were sometimes used in residential code compliance tools, were reduced in the 2006 IECC to seven pages consisting of a single (national) county map and a listing of climate zone assignments by county. Most of the obvious differences in the 2006 IECC are structural, but a few directly impact residential efficiency. The most significant differences are summarized below.

- New climate basis. The 2003 IECC's envelope requirements vary directly with heating degree-days (HDD, a measure of the severity of the winter climate).

There is also one compliance path (dubbed Simplified Prescriptive Requirements) that bases requirements on 17 climate zones defined by discrete HDD ranges. ${ }^{1}$ The 2006 IECC eliminates the need for local climatic data by defining climate zones entirely by geopolitical boundaries - state and county lines. There are eight of the latter climate zones that cover the entire U.S., including Hawaii and Alaska. $^{2}$

- Consolidated single- and multifamily requirements. The 2003 IECC has different efficiency requirements for single-family detached (one- and two-family dwellings) and low-rise multifamily (apartments, townhouses, etc., less than four stories above-grade). The multifamily requirements are notably less stringent than those for single-family residences. The 2006 IECC eliminated the distinction between the two building types, which has the effect of increasing energy efficiency in multifamily buildings.

- Envelope requirements decoupled from window-wall ratio (WWR). The 2003 IECC's envelope requirements (insulation R-values, fenestration U-factors) differ depending on the WWR of the candidate building. Homes with high WWRs are required to have better insulated envelopes than homes with low WWRs. The 2006 IECC, in contrast, has fixed envelope efficiency requirements regardless of the home's WWR. As shown in this analysis, the two codes have roughly equivalent envelope requirements at a WWR of $15 \%$, with the 2003 IECC being more stringent for higher WWRs and the 2006 IECC being more stringent for lower WWRs.

- Compliance paths eliminated. The 2006 IECC's switch from directly climatevarying requirements to purely geographically based requirements allowed for the

\footnotetext{
${ }^{1}$ There are actually 19 HDD ranges defined in the code, although only 17 appear in the residential section on Compliance by prescriptive specification on an individual component basis (502.2.4).

${ }^{2}$ The 2006 IECC further divides these eight zones into separate moisture regimes (moist, dry, and marine), but these have no effect on the requirements for residential buildings.
} 
elimination of the 2003 IECC's compliance path based on U-factor curves [Figures 502.2(1) through (6)]. The 2006 IECC's decoupling of envelope requirements from WWR allowed the elimination of all but one of the 2003 IECC's nine simplified prescriptive envelope tables [Tables 502.2.4(1) through (9)]. The result is that the efficiency requirements of the 2006 IECC are less volatile - they vary less from house to house and location to location than do those of the 2003 IECC.

- Rewritten simulated performance compliance path. The 2006 IECC contains an improved whole-building performance compliance path that, compared to the version in the 2003 IECC, is much clearer and better defined. It is likely less error prone and less amenable to loopholes that result in less efficient buildings than are possible under the prescriptive compliance path(s).

Although these most significant changes resulted from a proposal by DOE that was designed to be roughly energy neutral with respect to single-family detached buildings, such extensive format changes necessarily result in efficiency differences for many homes, depending on the particulars of location, house type, house design, and even compliance path. Additionally, there are other changes that were incorporated into the 2006 IECC that have some direct, if small, impacts on energy efficiency. For example, some requirements related to swimming pools and some metering requirements for electric power and lighting in non-dwelling portions of multifamily buildings were eliminated in the 2006 IECC.

The analysis described in this report evaluates residential efficiency resulting from the most straightforward compliance alternative in each code applied in each of two building types (single-family detached, multifamily), considering variations in a single significant design option (window-wall ratio [WWR]), and evaluated in an extensive range of U.S. climates.

In the residential portion of the IECC, the thermal envelope requirements dominate the code's impact on building efficiency and are thus the focus of this analysis. The prescriptive envelope requirements are examined via detailed simulation analysis in Section 2. Compliance paths other than the prescriptive path are addressed in Section 3. Code requirements other than those for the building envelope are discussed in Section 4. Finally, an appendix provides additional detail in evaluating the impact of decoupling envelope requirements from WWR. 


\section{Simulation Analysis of Prescriptive Thermal Envelope Measures}

The energy efficiency impacts of the changes to the IECC thermal envelope requirements were analyzed using building simulation software. This section describes the assumptions and methodology used in this analysis and presents the results.

\section{Methodology and Assumptions}

The EnergyGauge ${ }^{\mathrm{TM}}$ software $^{3}$ was used to determine the energy impacts of changes in envelope requirements. EnergyGauge ${ }^{\mathrm{TM}}$ is based on the DOE-2 energy simulation software developed by DOE (Lawrence Berkeley National Laboratory 1981). It was selected for this task because it is popular among residential energy raters and other design professionals familiar with residential energy codes and, because it is specifically designed for residential analysis and contains some convenient enhancements to DOE-2.

Two sets of buildings were simulated: one with energy efficiency levels set to match the prescriptive requirements of the 2003 IECC, and one with energy efficiency levels set to match the prescriptive requirements of the 2006 IECC. All inputs other than the changes in energy efficiency levels were identical between the two sets.

\section{Thermal Envelope Measures in the IECC}

The 2003 IECC envelope requirements used in this analysis are obtained from Tables 502.2.4(1) through (9) of that code. The 2006 IECC requirements are from Table 402.1.1 of that code. These requirements consist of insulation R-values $\left(\mathrm{hr} \cdot \mathrm{ft}^{2} \cdot{ }^{\circ} \mathrm{F} / \mathrm{Btu}\right)$ for envelope components - including ceilings, walls (both above ground and basement), and floors - and U-factors (Btu/hr· $\left.\cdot \mathrm{ft}^{2} \cdot{ }^{\circ} \mathrm{F}\right)$ for windows and doors. Both the $2003 \mathrm{IECC}$ and the 2006 IECC require the thermal envelope to be sealed to limit air leakage, but specify no test or other means of quantifying the achieved level of air sealing. Therefore, identical air leakage assumptions were used for both codes. The envelope requirements analyzed here are referred to as the prescriptive requirements.

Both the 2003 IECC and the 2006 IECC have other compliance paths that arguably could result in more or less efficiency. In particular, both codes allow trade-offs among building components such that an overall envelope conductance ("UA" value) is maintained, a scheme that is popular among code users and, for example, is the basic compliance path exploited by DOE's own REScheck ${ }^{\mathrm{TM}}$ software. Because of the discreteness in available products (e.g., R-15 batts and R-19 batts are readily available, but not R-17), it is often possible to achieve UA-based compliance with slightly less overall efficiency than by strictly following the prescriptive tables. Similarly, both codes permit compliance via computer simulation of whole-house energy consumption, a compliance path that allows even greater departure from the simple prescriptive tables.

However, because similar compliance paths exist in both codes and DOE is unaware of data that would confidently determine the numbers of homes that are complied by each

\footnotetext{
${ }^{3}$ http://www.energygauge.com/
} 
path, this analysis is based on the more straightforward prescriptive tables that are similar in format between the codes and confidently establish each code's intent without relying on unverified estimates of compliance path usage.

\section{Building Prototypes}

Separate analyses were conducted for single-family and multifamily buildings because the 2003 IECC has different requirements for the two building types. The prototypes used in the energy simulations are intended to represent a typical new one- or two-family house or a low-rise multifamily building with R-2 occupancy (apartments, dormitories, etc.), R-4 occupancy (small assisted living facilities), or a townhouse building. Four foundation types are examined: vented crawlspace, slab on-grade, heated basement with wall insulation, and unheated basement with insulation in the floor above the basement. Table 1 shows the assumed characteristics for the single-family prototype.

Table 1. Single-Family Prototype Characteristics

\begin{tabular}{|c|c|c|}
\hline Parameter & Assumption & Notes \\
\hline Conditioned floor area & $2400 \mathrm{ft}^{2}$ & $\begin{array}{l}\text { Characteristics of New } \\
\text { Housing, U.S. Census } \\
\text { Bureau }\end{array}$ \\
\hline Footprint and height & $\begin{array}{l}30 \mathrm{ft} \text {. by } 40 \mathrm{ft} ., 2 \text {-story, } 8.5 \\
\text { ft. high ceilings }\end{array}$ & \\
\hline $\begin{array}{l}\text { Area above unconditioned } \\
\text { space }\end{array}$ & $1200 \mathrm{ft}^{2}$ & \\
\hline Area below roof/ceilings & $\begin{array}{l}1200 \mathrm{ft}^{2}, 70 \% \text { with attic, } \\
30 \% \text { cathedral }\end{array}$ & \\
\hline Perimeter length & $140 \mathrm{ft}$ & \\
\hline Gross wall area & $2380 \mathrm{ft}^{2}$ & \\
\hline $\begin{array}{l}\text { Window area (as a percent } \\
\text { of gross wall area) }\end{array}$ & $\begin{array}{l}\text { Zones 1-2: } 17 \% \\
\text { Zone 3: } 16 \% \\
\text { Zone 4: } 15 \% \\
\text { Zones 5-8: } 14 \%\end{array}$ & $\begin{array}{l}\text { Appendix A summarizes } \\
\text { survey data on window area }\end{array}$ \\
\hline Door area & $42 \mathrm{ft}^{2}$ & \\
\hline Internal gains & 91,436 Btu/day & 2006 IECC, Section 404 \\
\hline Heating system & $\begin{array}{l}\text { Natural gas furnace, } 78 \\
\text { Annual fuel utilization } \\
\text { efficiency }\end{array}$ & $\begin{array}{l}\text { Minimum manufacturing } \\
\text { standards. Two-thirds of } \\
\text { new houses heated by } \\
\text { natural gas. (Characteristics } \\
\text { of New Housing, U.S. } \\
\text { Census Bureau) }\end{array}$ \\
\hline Cooling system & $\begin{array}{l}\text { Central electric AC, } 13 \\
\text { Seasonal energy efficiency } \\
\text { ratio }\end{array}$ & $\begin{array}{l}\text { Minimum manufacturing } \\
\text { standards }\end{array}$ \\
\hline Water heating & Natural gas & \\
\hline
\end{tabular}


For a multifamily building prototype, the Census data (2006) shows that the size and number of units per building in new construction varies greatly. From the Census data (2006), the median number of units per building (including high rise) is in the range of 20 to 29 , with the median floor area per unit in the range of 1000 to $1199 \mathrm{ft}^{2}$. The multifamily prototype characteristics used here are:

- A rectangular two-story building, $30 \mathrm{ft}$ by $400 \mathrm{ft}$, consisting of 20 units in a row, each with $1200 \mathrm{ft}^{2}$ of conditioned floor area.

- $12,000 \mathrm{ft}^{2}$ roof/ceiling area

- $12,000 \mathrm{ft}^{2}$ floor area above unconditioned basements or crawl spaces. 860 lineal $\mathrm{ft}$ foundation perimeter. $6880 \mathrm{ft}^{2}$ of $8 \mathrm{ft}$ high basement wall area for the heated basement scenario.

- $13,760 \mathrm{ft}^{2}$ of gross exterior wall area (this is the above-ground area, excluding basement wall area)

- $42 \mathrm{ft}^{2}$ of exterior door area per dwelling unit

- 54668 Btu/day internal gains per dwelling unit (2006 IECC)

- Window area is conservatively ${ }^{4}$ estimated at $14 \%$ of the conditioned floor area

- The heating, cooling, and water heating systems characteristics are the same as for the single-family prototype (each dwelling unit has its own separate heating and cooling equipment)

\section{Climate Locations}

This analysis includes simulations in each of the 239 locations for which TMY2 $2^{5}$ weather data are available. Figure 1 shows the TMY2 locations superimposed on the 2006 IECC climates zones. Although Alaska and Hawaii are not shown, they are well represented with 17 and 4 TMY2 locations, respectively. Climate zone 8 exists only in Alaska and all of Hawaii is designated as zone 1.

\footnotetext{
${ }^{4}$ This is conservative in the sense that it is at the higher end of the range of average window areas, and therefore establishes more stringent requirements for the 2003 IECC and lessens the chance of a falsepositive DOE determination inappropriately mandating state action.

${ }^{5}$ See http://rredc.nrel.gov/solar/old_data/nsrdb/tmy2/
} 


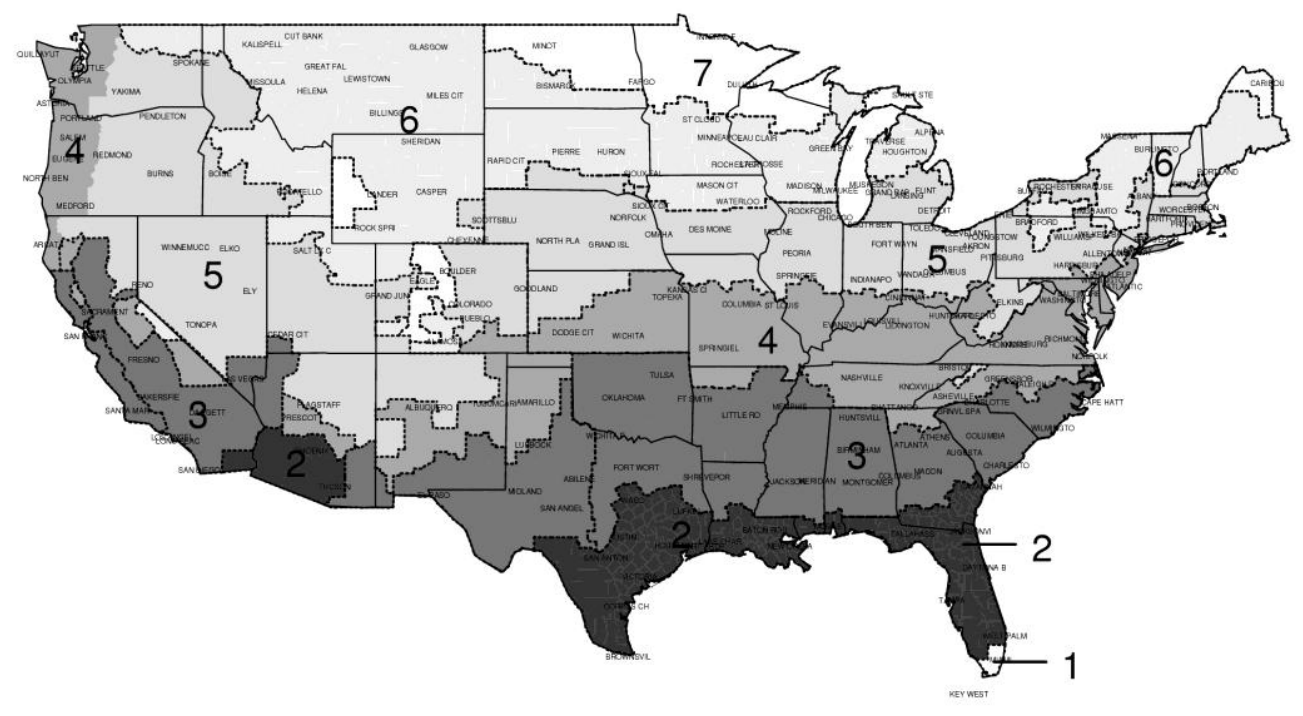

Figure 1. 239 Locations Analyzed and the Climate Zones of the 2006 IECC

\section{Aggregation Methodology}

The results of the numerous energy simulations are aggregated based on a weighted averaging within each 2006 IECC climate zone. This aggregation involves the following steps:

- Averaging across TMY2 locations within each climate zone

- Averaging across climate zones to achieve a national average estimate

- Averaging across foundation types to achieve overall prototype averages

- Averaging across building type (single- and multifamily) to achieve a final overall residential result.

The assumptions for aggregating all the simulation results to a single national average are documented below.

\section{Combining Across TMY2 Locations Within Climate Zones}

The energy savings by climate zone were determined using the results from the 239 TMY2 locations weighted by year 2000 new residential building permits from the U.S. Census Bureau (http://www.census.gov/const/www/permitsindex.html). 


\section{Climate Zone Shares}

Results are aggregated from the 239 locations to climate zone and national averages using weights based on new residential building permit data by city for the year 2000 . Table 2 contains the shares of national construction by climate zone. More than $90 \%$ of the construction is in zones 2 to 5 . Climate zone 7 and 8 are combined here because zone 8 has only a tiny fraction of the national construction activity.

Table 2. Housing Start Shares by Climate Zone

\begin{tabular}{|c|c|}
\hline $\begin{array}{c}\text { Climate } \\
\text { Zone }\end{array}$ & $\begin{array}{c}\text { Percentage } \\
\text { of Building } \\
\text { Permits }\end{array}$ \\
\hline 1 & 2 \\
\hline 2 & 19 \\
\hline 3 & 27 \\
\hline 4 & 19 \\
\hline 5 & 27 \\
\hline 6 & 6 \\
\hline $7 \& 8$ & 0.3 \\
\hline
\end{tabular}

The 2003 IECC defined 19 HDD ranges that have completely different borders from the 8 zones in the 2006 IECC zones. Table 3 shows an estimate of the distribution of those HDD ranges as they relate to each of the 2006 IECC climate zones. Each column, which should approximately sum to 100, shows the percentages of populated locations in a 2006 IECC zone that are located in each of 19 HDD range-based zones of the 2003 IECC. The locations counted are taken from the USGS Populated Places dataset, ${ }^{6}$ which lists cities, towns, and even smaller entities such as large rural subdivisions, trailer parks, etc. Table 3 , therefore, describes the comparative distribution of geography rather than of population, housing starts, square footage of new homes, or other potentially related quantities.

\footnotetext{
${ }^{6}$ Part of the USGS Geographic Names Information System (see http://geonames.usgs.gov/domestic/download_data.htm)
} 
Table 3. Percentage of Locations in Each 2006 IECC Climate Zone that Would Have Been in Each 2003 IECC Climate Zone.

\begin{tabular}{|c|c|c|c|c|c|c|c|}
\hline \multirow{2}{*}{$\begin{array}{c}2003 \\
\text { IECC } \\
\text { Climate } \\
\text { Zone }\end{array}$} & \multicolumn{7}{|c|}{2006 IECC Climate Zone } \\
\hline & 1 & 2 & 3 & $\begin{array}{c}4 \\
\text { except } \\
\text { Marine }\end{array}$ & $\begin{array}{c}5 \text { and } \\
\text { Marine } \\
4\end{array}$ & 6 & $7 \& 8$ \\
\hline 1 & 100 & 5 & 0 & 0 & 0 & 0 & 0 \\
\hline 2 & 0 & 20 & 0 & 0 & 0 & 0 & 0 \\
\hline 3 & 0 & 40 & 22 & 0 & 0 & 0 & 0 \\
\hline 4 & 0 & 31 & 10 & 0 & 0 & 0 & 0 \\
\hline 5 & 0 & 3 & 18 & 0 & 0 & 0 & 0 \\
\hline 6 & 0 & 0 & 28 & 0 & 0 & 0 & 0 \\
\hline 7 & 0 & 0 & 16 & 4 & 0 & 0 & 0 \\
\hline 8 & 0 & 0 & 6 & 9 & 0 & 0 & 0 \\
\hline 9 & 0 & 0 & 0 & 13 & 1 & 0 & 0 \\
\hline 10 & 0 & 0 & 0 & 28 & 6 & 0 & 0 \\
\hline 11 & 0 & 0 & 0 & 41 & 8 & 0 & 0 \\
\hline 12 & 0 & 0 & 0 & 5 & 28 & 0 & 0 \\
\hline 13 & 0 & 0 & 0 & 0 & 31 & 0 & 0 \\
\hline 14 & 0 & 0 & 0 & 0 & 20 & 12 & 0 \\
\hline 15 & 0 & 0 & 0 & 0 & 6 & 81 & 3 \\
\hline 16 & 0 & 0 & 0 & 0 & 0 & 5 & 6 \\
\hline 17 & 0 & 0 & 0 & 0 & 0 & 2 & 85 \\
\hline 18 & 0 & 0 & 0 & 0 & 0 & 0 & 5 \\
\hline 19 & 0 & 0 & 0 & 0 & 0 & 0 & 2 \\
\hline
\end{tabular}

\section{Foundation Shares}

The IECC has separate requirements for each of three foundation types: floors, basement walls, and slabs on-grade. Floors include floors over unconditioned spaces such as crawlspaces, unheated basements, and garages. Floors also include floors over outside air (e.g., buildings on piers or cantilevered floors). Basement wall requirements apply to conditioned basements.

The requirements for the 2003 and 2006 IECC are analyzed here by examining the four most common foundation configurations: floors above vented crawlspaces, floors above unconditioned basements, conditioned basements with wall insulation, and slabs on-grade with perimeter insulation. Simulation results are averaged using weighting factors based on new-home foundation shares. These foundation shares are estimated from the Census Bureau data for 2004 housing characteristics data (http://www.census.gov/const/www/charindex.html) shown in Table 4. 
Table 4. Foundation Type Shares (percent) by Census Zone

\begin{tabular}{|l|r|r|r||}
\hline & Basement & Slab & \multicolumn{1}{|l|}{ Crawlspace } \\
\hline Northeast & 84 & 13 & 3 \\
\hline Midwest & 76 & 17 & 6 \\
\hline South & 12 & 70 & 17 \\
\hline West & 15 & 65 & 20 \\
\hline Total & 31 & 54 & 15 \\
\hline
\end{tabular}

These data provide the fraction of new residences having basements, but do not distinguish conditioned from unconditioned basements. We estimate this split to be $75 \%$ conditioned, 25\% unconditioned based on data from the DOE Residential Energy Consumption Survey (http://www.eia.doe.gov/emeu/recs/).

Because foundation share data is available only for Census zones, not 2006 IECC climate zones, it is necessary to estimate the climate zone shares from Census data and general knowledge about regional construction techniques (e.g., basements are almost never used in the far south). Table 5 shows the shares assumed in this analysis.

Table 5. Foundation Type Shares (percent) by 2006 IECC Climate Zone

\begin{tabular}{|c|c|c|c|c|}
\hline $\begin{array}{c}\text { Climate } \\
\text { Zone }\end{array}$ & $\begin{array}{c}\text { Heated } \\
\text { Basement }\end{array}$ & Crawlspace & $\begin{array}{c}\text { Slab- } \\
\text { on- } \\
\text { Grade }\end{array}$ & Unheated \\
\hline 1 & 0 & 0 & 100 & 0 \\
\hline 2 & 0 & 5 & 95 & 0 \\
\hline 3 & 10 & 15 & 70 & 5 \\
\hline 4 & 30 & 20 & 40 & 10 \\
\hline 5 & 45 & 20 & 20 & 15 \\
\hline 6 & 65 & 10 & 5 & 20 \\
\hline $7 \& 8$ & 70 & 5 & 5 & 20 \\
\hline
\end{tabular}

\section{Single-Family and Multifamily Shares}

Building permit data for 2004 and 2005 indicates that $20 \%$ of new construction in terms of total living units is multifamily (Census 2006). Of these, $22 \%$ of the new multifamily units are in buildings of four stories or more in height and fall under the IECC's commercial provisions (Census, New Char. 2006). Therefore, about $16 \%$ of all living units in the residential building classification of the IECC are in multifamily buildings. This figure is used to aggregate the single-family and multifamily results. 


\section{Analysis Results}

This section provides the results of the comparative analysis of the envelope requirements of the 2006 IECC and the 2003 IECC. Table 6 shows the average annual energy savings per house for the 2006 IECC. The final column shows this savings as a percentage of total annual space heating and cooling. A positive number indicates that the 2006 IECC is more efficient than the 2003 IECC. The averages in the final column and row are the weighted results that account for construction shares by foundation type and climate zone. The remainder of the table does not account for actual construction shares. Rather, it shows the impacts on a hypothetical house built with a particular foundation in each climate zone.

Based on the weighted average simulation results, the two codes have nearly identical efficiency in terms of prescriptive envelope measures for single-family houses. Notable exceptions are Zone 3, for which the 2006 IECC is less efficient than the 2003 code, and Zone 5, for which the 2006 IECC is more efficient. Table 6 confirms that DOE's change proposal was successful in achieving energy neutrality while reformatting the code. It also highlights, however, that there is some give and take in efficiency between locations.

Table 6. Annual Energy Savings (MBtu) of 2006 IECC Compared to 2003 IECC - Single-Family House

\begin{tabular}{|l|c|c|c|c|c|c||}
\hline & \multicolumn{5}{|c|}{ Foundation Type } & \\
\cline { 2 - 5 } Climate \\
Zone & $\begin{array}{l}\text { Heated } \\
\text { Basement }\end{array}$ & $\begin{array}{l}\text { Crawl } \\
\text { Space }\end{array}$ & $\begin{array}{l}\text { Slab- } \\
\text { on- } \\
\text { Grade }\end{array}$ & $\begin{array}{l}\text { Unheated } \\
\text { Basement }\end{array}$ & Average & $\begin{array}{c}\text { Percent } \\
\text { Savings }\end{array}$ \\
\hline Zone 1 & 0.4 & 0.3 & 0.2 & 0.3 & 0.2 & 1 \\
\hline Zone 2 & -0.8 & 0.8 & 0.3 & -1 & 0.3 & 1 \\
\hline Zone 3 & -9.7 & -1.6 & -4.1 & -2.1 & -4.2 & -6 \\
\hline Zone 4 & 1 & -0.4 & -0.2 & -0.3 & 0.1 & 0 \\
\hline Zone 5 & 3.7 & 5.7 & 2.6 & 4.6 & 4 & 3 \\
\hline Zone 6 & 0.1 & 2.5 & -1 & 1.3 & 0.5 & 0 \\
\hline Zone 7 & -1.8 & 5.2 & 0.7 & 3.9 & -0.1 & 0 \\
\hline Average & 1 & 1.6 & -1.1 & 2 & 0 & 0 \\
\hline
\end{tabular}

Table 7 shows similar results for multifamily buildings. Because the 2003 IECC's requirements are considerably more lenient for multifamily buildings than for singlefamily buildings, but the 2006 IECC has identical requirements for the two building types, the 2006 IECC saves considerable energy compared to the weak requirements in the 2003 IECC for multifamily. 
Table 7. Annual Energy Savings (MBtu) of 2006 IECC Compared to 2003 IECC - Multifamily Dwelling Unit

\begin{tabular}{|c|c|c|c|c|c|c|}
\hline \multirow[b]{2}{*}{$\begin{array}{l}\text { Climate } \\
\text { Zone }\end{array}$} & \multicolumn{4}{|c|}{ Foundation Type } & \multirow[b]{2}{*}{ Average } & \multirow[b]{2}{*}{$\begin{array}{l}\text { Percent } \\
\text { Savings }\end{array}$} \\
\hline & $\begin{array}{l}\text { Heated } \\
\text { Basement }\end{array}$ & $\begin{array}{l}\text { Crawl } \\
\text { Space }\end{array}$ & $\begin{array}{l}\text { Slab- } \\
\text { on- } \\
\text { Grace }\end{array}$ & $\begin{array}{l}\text { Unheated } \\
\text { Basement }\end{array}$ & & \\
\hline Zone 1 & 1 & 1 & 0.8 & 0.9 & 0.8 & 7 \\
\hline Zone 2 & 3.8 & 4.6 & 4.3 & 4.5 & 4.3 & 12 \\
\hline Zone 3 & -3.1 & 2 & 0.6 & 1.5 & 0.5 & 1 \\
\hline Zone 4 & 7.3 & 6.8 & 4.7 & 6.2 & 6.1 & 6 \\
\hline Zone 5 & 14.8 & 16 & 12.7 & 15.3 & 14.7 & 13 \\
\hline Zone 6 & 6.4 & 7.8 & 5.5 & 7.3 & 6.3 & 5 \\
\hline Zone 7 & -3.2 & 1 & -1.3 & 0.6 & -2.2 & -1 \\
\hline Average & 9.7 & 8.7 & 3.7 & 9.9 & 6.4 & 8 \\
\hline
\end{tabular}

Table 8 shows the combined average results assuming $84 \%$ single-family and $16 \%$ multifamily. Overall, the 2006 IECC saves about $1 \%$ compared to the 2003 IECC.

Zones 3 and 5 again stand out with the greatest departure from the average, with the 2006 IECC faring best in Zone 5, worst in Zone 3.

Table 8. Annual Energy Savings (MBtu) of 2006 IECC Compared to 2003 IECC - Combined SingleFamily and Multifamily

\begin{tabular}{|c|c|c|c|c|c|c|}
\hline \multirow[b]{2}{*}{$\begin{array}{l}\text { Climate } \\
\text { Zone }\end{array}$} & \multicolumn{4}{|c|}{ Foundation Type } & \multirow[b]{2}{*}{ Average } & \multirow[b]{2}{*}{$\begin{array}{l}\text { Percent } \\
\text { Savings }\end{array}$} \\
\hline & $\begin{array}{l}\text { Heated } \\
\text { Basement }\end{array}$ & $\begin{array}{l}\text { Crawl } \\
\text { Space }\end{array}$ & \begin{tabular}{|l|} 
Slab- \\
on- \\
Grace \\
\end{tabular} & $\begin{array}{l}\text { Unheated } \\
\text { Basement }\end{array}$ & & \\
\hline Zone 1 & 0.5 & 0.4 & 0.3 & 0.4 & 0.3 & 2 \\
\hline Zone 2 & -0.1 & 1.4 & 0.9 & -0.1 & 0.9 & 3 \\
\hline Zone 3 & -8.6 & -1 & -3.3 & -1.5 & -3.4 & -5 \\
\hline Zone 4 & 2 & 0.8 & 0.6 & 0.7 & 1.1 & 1 \\
\hline Zone 5 & 5.5 & 7.3 & 4.2 & 6.3 & 5.7 & 5 \\
\hline Zone 6 & 1.1 & 3.3 & 0 & 2.3 & 1.4 & 1 \\
\hline Zone 7 & -2 & 4.5 & 0.4 & 3.4 & -0.4 & 0 \\
\hline Average & 2.4 & 2.7 & -0.3 & 3.3 & 1 & 1 \\
\hline
\end{tabular}

\section{Sensitivity Analysis}

The analysis above covers a limited set of assumptions including house size, shape, and design characteristics; operating conditions; heating and cooling system type and efficiency; and other characteristics that impact energy use. In this section, the code comparison results are examined for their sensitivity to variations in some of those key variables. Because the two code editions have very similar requirements in most locations, it will be shown that the code comparison results have very little sensitivity to the assumptions. 


\section{Window-Wall Ratio}

The component efficiency requirements of the residential building thermal envelope are constant with respect to window-wall ratio in the 2006 IECC. Therefore, a home with a high WWR will be permitted to have a higher overall envelope conductance than one with a low WWR because the windows have higher conductance than the opaque walls they displace. This is not the case with the 2003 IECC, where, as the WWR becomes higher, the required thermal resistance of the wall is increased to offset the greater thermal transmittance of the windows.

There has been concern that this change could result in an overall decrease in the stringency of the code. Indeed, it has been argued that the 2006 IECC permits an "all glass" house to be built without penalty. However, this effect is offset because while the 2003 IECC becomes very stringent at WWRs, it also becomes lenient at low WWRs, whereas the 2006 IECC does not.

A sensitivity analysis was performed to illustrate how much the window area percentage affects the code comparison. Table 9 shows how the stringency of the codes compares for a house with three WWRs: $12 \%, 15 \%$, and $18 \%$. The final row shows the savings (percent) of the 2006 IECC in terms of total heating and cooling costs. This illustrates that the 2006 IECC is more stringent at the low $12 \%$ WWR, less stringent at an $18 \%$ WWR, and about the same as the 2003 IECC at a $15 \%$ WWR.

Table 9. Annual Energy Savings (MBtu) of 2006 IECC Compared to 2003 IECC - Single-Family House

\begin{tabular}{||c|c|c|c||}
\hline $\begin{array}{l}\text { 2006 IECC } \\
\text { Climate Zone }\end{array}$ & $12 \%$ Window Area & $15 \%$ Window Area & $18 \%$ Window Area \\
\hline 1 & 1.4 & 1.1 & 0.0 \\
\hline 2 & 3.8 & 2.1 & 0 \\
\hline 3 & 0.3 & -2.9 & -6.2 \\
\hline 4 & 3.8 & 0.4 & -2.7 \\
\hline 5 & 6.6 & -2.5 & -0.7 \\
\hline 6 & 3.2 & -0.5 & -7.3 \\
\hline $7+8$ & 3.8 & 2.3 & -8.4 \\
\hline $\begin{array}{c}\text { National Average } \\
\text { as a percentage of } \\
\text { energy costs }\end{array}$ & 3.6 & 0.3 & -2.8 \\
\hline
\end{tabular}

Data collected from the REScheck IECC code compliance software ${ }^{7}$ for 7465 houses indicates that $35 \%$ of new houses have WWRs below 12\%, 23\% have WWRs between

${ }^{7}$ http://energycode.pnl.gov/REScheckWeb/ 
$12 \%$ and $15 \%, 18 \%$ have WWRs between $15 \%$ and $18 \%$, and $23 \%$ have WWRs at or above $18 \%$. Further, because the lower end of the WWR range is constrained by the necessity of egress windows and the dictates of simple aesthetics, there are very few homes having WWR substantially less than $12 \%$. And because studies show the average WWR to be near 15\% (see appendix), it follows that very few homes have very high WWRs - that is, the "all glass" house or even the very highly glazed house is relatively rare.

Based on the REScheck data, the median WWR is slightly below $15 \%$, and more houses have WWRs near the $12 \%$ level, where the 2006 IECC is more stringent than near the $18 \%$ level, where the 2003 IECC is more stringent. This illustrates that while the 2006 code loses stringency relative to the 2003 IECC for houses with high WWRs, this impact is relatively small and is offset by the gains that occur for houses with low WWRs.

The effect of window area by itself (independent of other changes in the envelope requirements in the 2006 IECC) on the code's energy efficiency is examined in detail in the appendix.

\section{Sensitivity to Other Assumptions}

The energy comparisons above were based on a typical two-story residence. However, for new houses, one-story buildings are nearly as common as two-story nationwide. Therefore, a code comparison was conducted for a $30 \mathrm{ft}$ by $60 \mathrm{ft}$ one-story house to compare with the results for the two-story house. Other assumptions, including the $15 \%$ WWR were held constant and only the slab on-grade foundation was considered.

The difference in average 2006 energy savings between one-story and two-story homes never exceeds \$11/year in any climate zone. At the national average level, the 2006 IECC shows a $0.3 \%$ greater savings for the one-story prototype. Therefore, the number of stories has little impact on the code comparison.

The impacts of a few other parameters were tested. The window orientation was varied from the baseline of equally distributed (north, south, east, west) by window area to both primarily north-south and primarily east-west. Additionally the internal heat gain (from lights, appliances, people, etc.) was reduced by $20 \%$. None of these variations had more than a $\$ 1$ impact on the national average difference between annual energy costs in the code comparison. 


\section{Other Compliance Paths}

The energy analysis of Section 2.0 compares the most straightforward prescriptive compliance path of each code. There are two other compliance paths in both the 2003 and 2006 IECC: the U-factor path and the simulated performance path. The building designer has the option of using any of these paths. These paths are intended by the code developers to represent equivalent levels of stringency to the prescriptive compliance path in both code versions, although the fundamental differences in the compliance paths means that they cannot have completely identical requirements in all cases.

\section{Compliance by U-Factor}

The U-factor approach is a close relative of the R-value-based prescriptive approach analyzed above. U-factors account for overall heat transfer rates through envelope components, accounting for all materials in each component - insulation, interior and exterior finish materials, framing members, structural sheathing, etc. This is in contrast to the R-value-based prescriptive approach, which expresses requirements in terms of insulation layers only. The codes' U-factors requirements are ostensibly consistent with the R-value requirements analyzed above, ${ }^{8}$ but the U-factor approach allows for greater flexibility in accounting for less common construction techniques such as structural insulated panels or insulated concrete forms that often cannot utilize the prescriptive approach.

The U-factors can also be combined into a whole-building envelope "UA" (U-factor multiplied by area) approach that allows trade-offs across the envelope components as long as the proposed house UA is less than or equal to the UA of a house exactly meeting the component U-factor requirements. In the 2003 IECC, these approaches are contained in Sections 502.2.1 and 502.2.2. In the 2006 IECC, these are contained in Sections 402.1.3 and 402.1.4. The U-factor approach has the same mechanical system and domestic hot water requirements as the prescriptive approach.

Table 10 shows the improvement in the building envelope UA (percent) for the 2006 IECC compared to the 2003 IECC. This is for the $2400 \mathrm{ft}^{2}$ prototype house. A negative value indicates the 2003 IECC has more stringent UA requirements. The averages in both the right-hand column and the bottom row are weighted by housing starts, foundation type, and climate zone. For example, few residential buildings in zone 3 have a basement foundation, so the weak requirement for heated basements in the 2006 IECC (no basement wall insulation is required) has little impact on the overall result. Overall, the 2006 IECC is about 5\% more stringent for single-family homes. This percentage improvement will be even higher for multifamily buildings.

\footnotetext{
${ }^{8}$ In the development of requirements for the 2003 IECC, the prescriptive requirements were derived to be as stringent as the U-factor requirements. In the 2006 IECC, this process was reversed-the U-factor requirements were derived from the prescriptive requirements.
} 
Table 10 Improvement in Whole Building Thermal Transmittance ("UA", percent) in the 2006 IECC - Single-Family House

\begin{tabular}{|c|c|c|c|c|c|}
\hline \multirow[b]{2}{*}{$\begin{array}{l}\text { Climate } \\
\text { Zone }\end{array}$} & \multicolumn{4}{|c|}{ Foundation Type } & \multirow[b]{2}{*}{ Average } \\
\hline & $\begin{array}{l}\text { Heated } \\
\text { Basement }\end{array}$ & $\begin{array}{l}\text { Crawl } \\
\text { Space }\end{array}$ & $\begin{array}{l}\text { Slab- } \\
\text { on- } \\
\text { Grace }\end{array}$ & $\begin{array}{l}\text { Unheated } \\
\text { Basement }\end{array}$ & \\
\hline Zone 1 & -2.7 & -1.3 & -3.6 & -1.3 & -3.6 \\
\hline Zone 2 & -1 & 11.4 & 8.8 & 11.4 & 8.9 \\
\hline Zone 3 & -33.5 & 4.1 & -1.6 & 4.1 & -4.2 \\
\hline Zone 4 & 11.9 & 8.1 & 6.4 & 8.1 & 8.6 \\
\hline Zone 5 & 13.3 & 11.2 & 10.3 & 11.2 & 11.9 \\
\hline Zone 6 & 5.1 & 8 & 3 & 8 & 5.9 \\
\hline Zone 7 & -2.7 & 9.4 & 4.5 & 9.4 & 0.7 \\
\hline Average & 4.6 & 8.1 & 4.4 & 8.6 & 5.1 \\
\hline
\end{tabular}

\section{Performance Approach}

Both the 2003 and 2006 IECC have a simulated performance compliance path that allows virtually any construction or equipment distinctive to be accounted for in determining compliance with the energy code. The proposed building can be designed to have almost any energy efficiency measures as long as the total estimated energy use is no greater than that of an identically sized reference building that exactly meets the prescriptive requirements. This includes all energy use related to space heating, space cooling, and domestic water heating. The total estimated energy use calculations needed to determine code compliance are typically done with commercially-available software products that establish prototype building descriptions for both the reference home and the proposed design.

In the 2003 IECC, the performance approach is contained in Chapter 4 and in the 2006 IECC it is contained in Section 404. In the 2006 IECC, the energy consumption metric used to establish code compliance is the total annual energy cost. This is an improvement over the 2003 IECC, which uses total annual "site energy"-the total energy measured at the building site without regard to upstream conversion efficiencies. The site energy metric can undervalue cooling and other functions that use electricity.

Both versions of the IECC establish "ground rules" to be used in the energy consumption calculations; for example, thermostat set points and internal gains. Assumptions for such variables that are not regulated by the code are generally required to be the same in both the reference and proposed prototypes. Differences in such assumptions between the 2003 and 2006 codes are therefore not expected to have major impacts on the relative efficiencies of the codes.

As mentioned above, the compliance target is established from the prescriptive requirements of each code. In both codes, the baseline depends on U-factor-based 
component requirements rather than $\mathrm{R}$-value-based ones. The linkage to prescriptive requirements is more straightforward in the 2006 IECC than in the 2003 code, where prescriptive component requirements are less straightforward and some of the prescriptive requirements are preempted by performance path-specific specifications.

Because the performance path uses the prescriptive requirements to set the basis for compliance in both code editions, the code comparison results are not expected to change significantly if the performance path were utilized for the comparison. If anything, the tighter coupling of prescriptive and performance paths and concomitant reduction in ambiguity of the 2006 performance path may result in less chance of its allowing a less efficient home than would the prescriptive path. 


\section{Other Code Requirements}

The simulation analysis above examined the primary differences in the thermal envelope prescriptive requirements of the IECC. Although the envelope requirements have the greatest influence on overall efficiency in residential buildings, the IECC does have other requirements that impact energy consumption. These are summarized below along with a brief discussion of how they differ between the 2003 and 2006 codes.

\section{Mechanical System Requirements}

Mechanical systems are addressed in Sections 503 and 504 of the 2003 IECC and Section 403 of the 2006 IECC. Both versions of the IECC contain limited requirements for space heating and cooling systems and domestic water heating (for showers, sinks, clothes washing, etc.). Efficiency requirements for these mechanical equipment types are preemptively set by Federal law and cannot be altered by state and local building codes. ${ }^{9}$ Consequently, both versions of the IECC effectively defer to the Federal requirements and hence can only set ancillary requirements for mechanical systems. Some of the ancillary differences between the two codes include:

- The primary requirements in the 2003 and 2006 IECC related to HVAC systems relate to insulating and sealing of air ducts and insulation of heating system water pipes. Air ducts are the most common distribution system in new housing and the 2006 IECC has some improvements in the insulation levels, particularly for return ducts. The 2006 IECC requires R-8 for ducts outside the conditioned space in almost all locations and situations. The 2003 code has similar or lower requirements for supply ducts in most locations and substantially lower requirements for return ducts in all locations. Only in very cold locations (HDD > 7500) do the 2003 IECC's supply requirements (R-11) exceed those of the 2006 IECC.

- The 2006 IECC includes a requirement that air handlers be sealed, whereas the 2003 IECC does not specifically mention air handlers. Air handlers are the component of the distribution system that encases the blower fan and the heat exchanger elements. The air handler is often a major source of leakage that can result in significant energy loss, and requiring effective sealing can save a substantial amount of energy.

The Florida Solar Energy Center conducted leak testing on 69 air handlers in new Florida houses (FSEC 2002). The combined return and supply air leakage in the air handler and adjacent connections was found to represent $5.3 \%$ of the system air flow ( $4.6 \%$ on the return side and $0.7 \%$ on the supply side). Testing in Phoenix found air handler leakage averaged 17, 31, 48, and $54 \mathrm{cfm}$ over four studies (Home Energy 2002). Ten percent of the total distribution system leakage

\footnotetext{
${ }^{9}$ There are provisions for jurisdictions to obtain waivers of the Federal preemption in certain situations, but no states have acquired such as of this writing.
} 
is from the air handler (25\% of leakage is from boots, $20 \%$ of leakage is from registers [leaks inside], and the remaining $45 \%$ of leakage is from the ducts).

Air distribution system losses are widely believed to increase energy use by $20 \%$ or even more in new homes with major parts of the distribution system located outside the conditioned space. Therefore, a carefully sealed air handler could potentially save $2 \%$ or more of heating and cooling energy. However, it is debatable whether the code's simply calling out air handlers as an item to be sealed will by itself result in a substantial improvement in how air handlers are sealed. The 2006 requirement establishes no metric by which a code official could verify whether the air hander is in fact sealed.

- The 2003 IECC has some minor requirements such as minimum settable ranges for thermostats and humidistat that were deleted from the 2006 IECC. These were deemed unnecessary by the code development committee, in large part because virtually any thermostat on the market would meet the requirements anyway.

- For domestic water heating, a few minor requirements in the 2003 IECC do not appear in the 2006 IECC. These largely apply to equipment not normally found in residential buildings (e.g., tanks with volume exceeding 140 gallons) and are not expected to impact residential energy consumption.

- The 2003 IECC has requirements for swimming pool heater controls and pool covers that are not in the 2006 IECC.

\section{Administrative}

Both the 2003 and 2006 IECC have a chapter that addresses administrative requirements for both residential and commercial buildings. These administrative requirements cover the scope and applicability of the code and information related to inspection and identification of measures. Although the requirements are similar between the two codes, the 2006 IECC has condensed and simplified them in places. The administrative chapter does not set any energy efficiency requirements and therefore, does not impact the determination for the 2006 IECC. 


\section{Conclusion}

Comparison of the efficiency of the 2003 and 2006 IECC is complicated by the extensive reformatting of the code in the 2006 edition. There are many cases where the 2006 is more efficient than the 2003 IECC, and many cases where it is less efficient than the 2003 IECC. Results vary by climate zone and by building design. The 2006 is generally more efficient in Zone 5 and the 2003 is generally more efficient in Zone 3 (based on the 2006 IECC climate zones). All other factors being equal, the 2003 IECC tends to be more efficient for buildings with a high window-wall ratios, whereas the 2006 IECC tends to be more efficient at a lower window-wall ratios. The stringency of the envelope requirements for multifamily buildings has improved in most cases in the 2006 IECC.

On the basis of an overall national average, accounting for all factors, the 2006 IECC will modestly improve residential energy efficiency. 


\section{References}

Baylon, D., S. Borelli, and M. Kennedy, 2000. Baseline Characteristics of the Residential Sector in Idaho, Montana, Oregon, and Washington. Prepared for the Northwest Energy Efficiency Alliance by Ecotope, Seattle, Washington.

California Energy Commission. 2000. Low-Rise Multifamily Building New Construction Characteristics Study. Sacramento, California.

Florida Solar Energy Center. 2002. Cummings, J., Withers, C., Gu, L., McIlvaine J., Fairey, P., and Lombardi, M. "Field Testing and Computer Modeling to Characterize the Energy Impacts of Air Handler Leakage," FSEC-CR-1357-02. http://www.fsec.ucf.edu/bldg/pubs/cr1357/index.htm

Home Energy. 2002. http://homeenergy.org/hewebsite/2002features/19-1/19$\underline{1 \text { text.html }}$

International Code Council. 2006. International Energy Conservation Code: 2006 Edition.

International Code Council. 2003. International Energy Conservation Code: 2003 Edition.

LBNL, 1981. DOE-2 Engineering Manual, Version 2.1A. Lawrence Berkeley National Laboratory and Los Alamos National Laboratory, LBL Report, No. LBL-11353; DOE-2 User Coordination Office, Berkeley, CA.

Pacific Gas and Electric (PG\&E). 2001. Residential New Construction Study. San Francisco, California.

U.S. Census Bureau. 2006 Characteristics of New One-Family Houses Completed http://www.census.gov/const/www/charindex.html\#singlecomplete.

U.S. Census Bureau. 2006 Building Permits

http://www.census.gov/const/www/C40/table1.html

U.S. Department of Energy. Energy Information Administration. (2006a). Electric Power Monthly. http://tonto.eia.doe.gov/ftproot/electricity/epm/02260603.pdf

U.S. Department of Energy. Energy Information Administration. (2001). Residential Energy Consumption Survey. http://www.eia.doe.gov/emeu/recs/recs2001/hc pdf/housunits/hc1-1a climate2001.pdf

U.S. Department of Energy. Energy Information Administration. (2006b). Annual Energy Outlook. http://www.eia.doe.gov/oiaf/aeo/pdf/aeotab_3.pdf 


\section{APPENDIX}

\section{Elimination of Window Area Dependencies}




\section{Appendix - Elimination of Window Area Dependencies}

One major characteristic of the IECC that changed between 2003 and 2006 is the structure of the envelope requirements. This change in structure is described below. This change raised considerable concern during the code development process because window (and other requirements) of the 2006 code remain unchanged as the window-wall area ratio (WWR) increases in a building design. Because there are no limits on the WWR, it is often said that the 2006 IECC allows unlimited window area - an all-glass house - with no penalty. The 2003 IECC, in contrast, has progressively more stringent requirements for envelope component efficiencies as WWR increases.

It is important to note that there are other aspects of the code that changed between 2003 and 2006 and therefore, the effect of the "unlimited window area" change must be considered with all the other changes in combination in making the determination. The main body of this report examines all code changes together. However, because of the concern during the 2006 code revision process that this window area issue reduced stringency, this appendix is included to examine the issue in isolation.

The 2003 IECC contains requirements for an overall thermal transmittance $\left(U_{o}\right)$ for envelope components such as walls, ceilings, and floors. This includes all elements of an envelope component; for example, walls include windows and doors in addition to the general opaque wall area (this will be referred to here as the gross wall area). Because windows normally have much higher heat transfer rates than opaque walls, it becomes more difficult to meet the overall wall thermal transmission requirement as the WWR becomes higher. More insulation or more energy efficient windows must be used for a house with a higher window area compared to an otherwise identical house with a lower window area. This effect can be observed by comparing how the requirements change from Tables 502.2.4(1) through Table 502.2.4(6) (i.e., from the lowest to highest window percentage) in the 2003 IECC for any given climate zone.

In contrast, the 2006 IECC establishes requirements by specific building element. There are separate requirements for windows, doors, and opaque walls. The ratio of window area to gross wall area has no impact on those prescriptive requirements - all housing (single-family or multifamily) within a climate zone has the same window and opaque wall requirements regardless of the window area or other design aspects. This fundamental change in format of the envelope requirements greatly simplifies the code but alters the stringency of the code depending on the building design.

As mentioned above, when this revision was being considered for inclusion in the 2006 IECC, there were major concerns that the change in requirements as a function of WWR might lower the energy efficiency of the code. This could happen in two ways:

1) The 2006 IECC has less stringent requirements for buildings with high WWR than the 2003 IECC. A house complying with the 2006 IECC will be less energy efficient than an identical house design complying with the 2003 IECC if the WWR is high enough. 
2) The change in the code may actually lead builders to increase window areas. This is because code requirements no longer become more stringent as the WWR increases. Therefore, the incremental cost of adding more windows can be lower under the 2006 IECC than under the 2003 IECC because component efficiencies no longer need to be improved.

These two issues will be addressed separately below.

\section{Is the 2006 IECC less stringent than the 2003 IECC because of its leniency with buildings with high window-wall ratios?}

It is true that the prescriptive requirements in the 2006 IECC are less stringent than those of the 2003 IECC if the WWR is high enough (ignoring other differences). Comparing the two codes, the 2003 IECC gains in stringency relative to the 2006 IECC as the WWR of a building design increases. Beyond some WWR threshold, which may differ depending on location, building type, and house design, the 2003 IECC becomes more stringent than the 2006 IECC for the prescriptive compliance path. However, the reverse is also true for the same reasons - below that WWR threshold, the 2003 IECC is less stringent than the 2006 IECC. For the 2006 IECC determination, a key question therefore is whether on a national average basis, the WWR in new residential buildings is below this threshold or above it. If the average WWR is below this transition point, the change in the format of the envelope requirements in the 2006 code will increase the stringency of the code, not decrease it.

We have collected available data on the window area characteristics of new residential buildings. Figure A.1 summarizes the data on the window area as a percentage of either the gross wall area or the conditioned floor area in new residences. (Surveys reporting both floor area and wall area suggest that the average floor area is about the same as the average wall area, although there is some variability depending on the size and shape of the building.) The national average WWR appears to be approximately $14 \%$, with southern/warm locations (Florida, California) tending to be somewhat higher and northern/cold locations (Montana, New Hampshire) somewhat lower. 


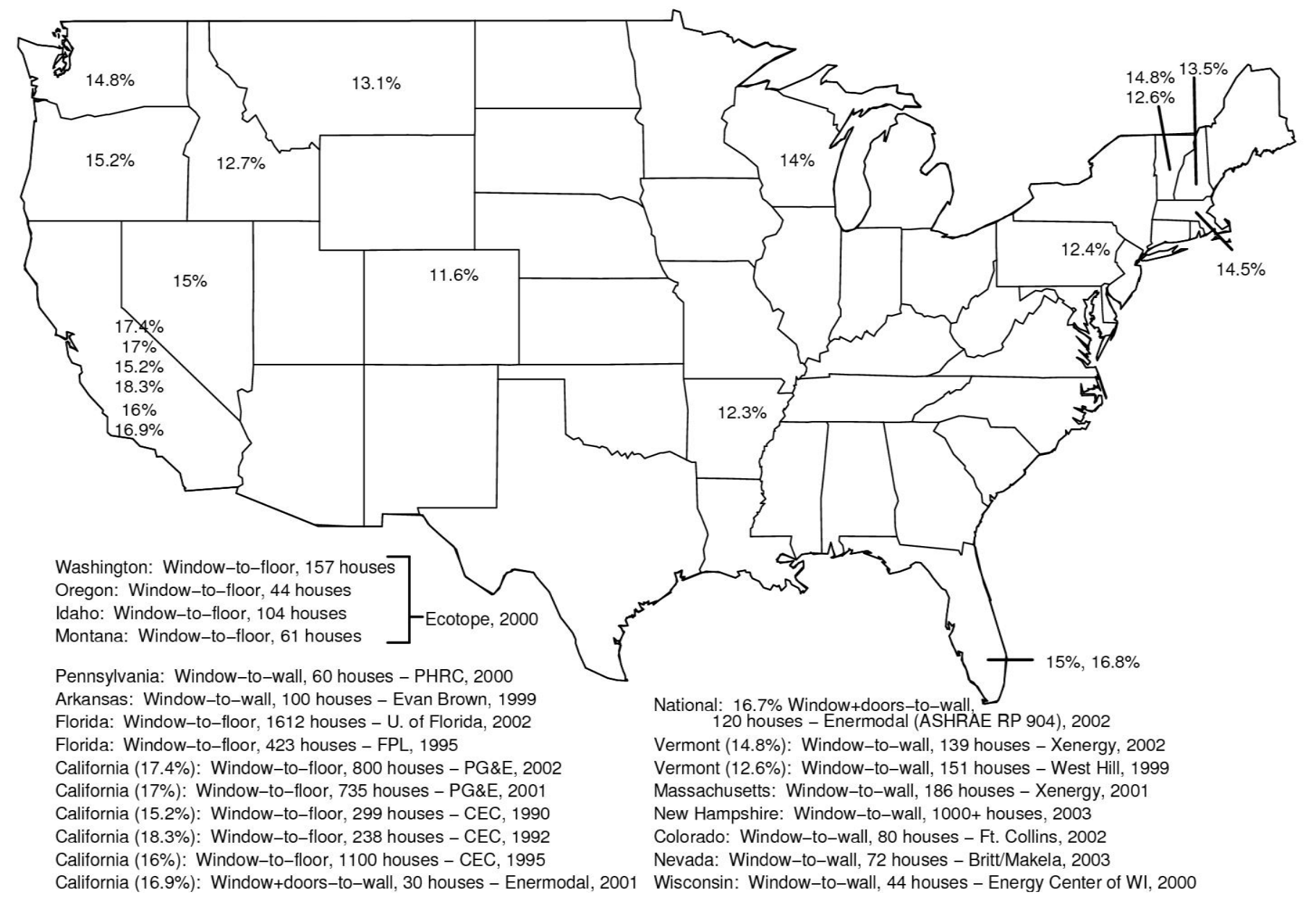

Figure A- 1. Window Area Percentages in New Residential Buildings

Table A.1 shows the threshold WWRs by climate zone. In homes with WWRs below these transition points, the 2006 IECC has more stringent gross wall requirements than the 2003 IECC. This is determined by comparing gross wall U-factor requirements from the 2003 and 2006 IECC. The 2003 IECC requirements are from the $\mathrm{U}_{\mathrm{o}}$-Factor requirements in Figure 502.2(1) for "Detached One- and Two-Family Dwellings." Results are aggregated to the climate zone level by weighting by housing starts. The 2006 IECC requirements are from Table 402.1.2 and are by definition set by these eight climate zones ${ }^{10}$.

\footnotetext{
${ }^{10}$ The $15 \mathrm{ft}^{2}$ glazed fenestration exemption of Section 402.3 .3 is assumed to have U-1.2 single-pane windows in Zones 1-4 and U-0.8 double-pane windows in Zones 5-8. Two 20- $\mathrm{ft}^{2}, \mathrm{U}-0.35$, doors are assumed. The $15 \%$ of exempt glazing is included in the transition window area percentage calculation but the door area is not.
} 
Table A- 1. Window-Wall Ratios (percent) At Which 2003 IECC and 2006 IECC Have Equivalent Gross Wall Requirements (Single-Family)

\begin{tabular}{|c|c|c|c||}
\hline $\begin{array}{l}\text { 2006 IECC } \\
\text { Climate } \\
\text { Zone }\end{array}$ & Threshold WWR & $\begin{array}{l}\text { Estimated Average } \\
\text { WWR for New } \\
\text { Buildings }\end{array}$ & $\begin{array}{l}\text { Code Edition with More } \\
\text { Stringent Average Wall } \\
\text { Un }_{0} \text {-factor }\end{array}$ \\
\hline 1 & $15.1 \%$ & $15-17 \%$ & 2003 \\
\hline 2 & $19.6 \%$ & $15-17 \%$ & 2006 \\
\hline 3 & $15.3 \%$ & $15-17 \%$ & 2003 \\
\hline 4 & $16.1 \%$ & $12-15 \%$ & 2006 \\
\hline 5 & $18.6 \%$ & $12-15 \%$ & 2006 \\
\hline 6 & $13.4 \%$ & $12-15 \%$ & Equal \\
\hline $7+8$ & $14.2 \%$ & $12-14 \%$ & 2006 \\
\hline
\end{tabular}

Table A.1 also contains the estimated average WWR in new homes by 2006 IECC climate zone. ${ }^{11}$ These estimates are based on the survey data shown in Figure A.1. Table A.1 shows the code edition that is estimated to have the more stringent requirements on average.

It appears that for all but Zone 1 (essentially the Miami area and Hawaii) and Zone 3, the 2006 IECC has equivalent or more stringent wall requirements than the 2003 IECC. In the colder zones where envelope U-factors are more important, ${ }^{12}$ the 2006 IECC has more stringent wall requirements than the 2003 IECC. These conclusions are based on averages - there will be new buildings in all locations for which one code or the other is more stringent.

Data from the on-line (web-based) version of REScheck code compliance software was examined. ${ }^{13}$ This is perhaps the most pertinent data available because it is based on actual IECC code compliance. ${ }^{14}$ The mean window area of 7465 single-family houses is $14.7 \%$ with a standard deviation of $7.2 \%$. The median window area is $13.8 \%$. The REScheck data is from a diverse set of U.S. locations, with Texas most common (23\% of the houses), followed by New Jersey (10\%), Pennsylvania (7\%), Colorado (6\%), and Wisconsin $(5 \%)$. These data confirm that average residential WWRs are generally at or below the threshold WWRs, suggesting that the 2006 IECC will be, on average, slightly more stringent than the 2003 IECC.

\footnotetext{
${ }^{11}$ Zone 8 includes only northern Alaska, where there is very little construction; it is therefore combined with Zone 7.

${ }^{12} \mathrm{U}$-factors are proportionately more important for heating than for cooling.

${ }^{13} \mathrm{http}$ ://energycode.pnl.gov/REScheckWeb/

${ }_{14}$ It is not known how many of these REScheck runs represent buildings actually built or even how many were ultimately submitted to the applicable code compliance body; some runs may have been experimental in nature and never used in practice. They do, however, represent runs that software users saved for future retrieval.
} 
There is much less survey data in all locations for low-rise multifamily buildings ${ }^{15}$. A California study (CEC 2000) of 142 new multifamily buildings throughout the state had an average window-floor area ratio (WFR) of 14\%-less than the average for California single-family homes. Another study of 95 new California multifamily buildings found an even lower WFR of 9\% (PG\&E 2001) and a follow-up study again found 9\% for 127 buildings. The WWR may exceed the WFR for multifamily structures as a consequence of the geometry of the larger building size. However, the on-line REScheck data for 288 multifamily buildings indicates an average WWR of $14.6 \%$ - only slightly higher than the $13.8 \%$ average for single-family houses. The 2003 IECC has much less stringent gross wall U-factor requirements for multifamily buildings than for single-family buildings while the 2006 IECC requirements do not vary by residential building type. Because of the lenient wall requirements in the 2003 IECC, the 2006 IECC will have more stringent multifamily wall requirements than the 2003 for all but buildings with a very high WWR. For example, at even a very high WWR of 30\%, Table 502.2.4(9) of the 2003 IECC has higher (less stringent) glazing U-factors from 3500 to 7000 HDD than the U-0.40 and U-0.35 requirements in the 2006 IECC. This HDD range encompasses most of the population of the northern half of the U.S.

\section{Will Window Areas Increase?}

The 2006 IECC's WWR-insensitve format eliminates the stringency "penalty" for adding more windows to a house for the prescriptive compliance path. Consequently, the cost to a builder of increasing the window area is less under the 2006 IECC than under the 2003 IECC. There is a reasonable concern that this could result in greater energy use by IECC-compliant houses as builders install more windows in response to their lower effective cost. The important questions are whether builders will increase the window area of their homes and, if so, how much and how often?

Basic economic theory suggests that there should be some increase in window area because the cost will be lower than it would be under the 2003 IECC. However, the Department of Energy is unaware of data suggesting that this happens in practice. Even windows with modest energy efficiency are expensive compared to the opaque walls they displace. Increasing a home's window area results not only in higher cost for the window units, but increases the cost of framing, attaching exterior finish materials, and possibly insulating the wall. Consequently, basic economic theory also suggests that there is motivation for builders to limit the size and number of window units regardless of the local code's sensitivity (or lack thereof) to WWR. The cost of improved energy efficiency is normally only a small fraction of the total cost of the window, estimated at 10 to $15 \%$ (see, for example, http://www.toolbase.org/Building-Systems/Windows/low-ewindows).

The question of whether a WWR-sensitive code will reduce the average regional WWR can be partly answered by examining homes in locations without such a code or without any enforced energy code. The Department is unaware of evidence that such locations

\footnotetext{
${ }^{15}$ The IECC defines residential multifamily buildings as three stories or less above-grade. High-rise multifamily must meet commercial building requirements in Chapters 7 and 8 of the IECC.
} 
have substantially higher glazing areas than jurisdictions that enforce a code sensitive to WWR. One notable example is the Oregon state energy code, which is identical in format to the 2006 IECC with regard to WWR and envelope efficiency. The average WWR in new Oregon residences appears to be in line with both the national average and neighboring Washington, which used the 2003 IECC format at the time of the survey (Baylon, Borrelli and Kennedy 2000).

A final observation: for buildings with very high WWRs, the 2003 IECC requirements can be quite stringent, far exceeding even Energy Star levels. Studies in California and Massachusetts suggest that most buildings with these high WWRs are failing to meet the corresponding stringent envelope requirements. Thus, it is quite possible that the higher stringency mandated by the 2003 IECC for high WWRs are not regularly enforced. ${ }^{16}$ This suggests that builders may be balking at what they consider onerous requirements in the 2003 IECC (California does not use the IECC but has a code with a similar format) and code officials have not always been successful at enforcing the full requirements. Therefore, the difference in requirements between the 2003 and 2006 IECC for high window area "on paper" may not translate into actual differences in new buildings under the codes in these cases. At low WWRs, on the other hand, builders have incentive to take advantage of the 2003 IECC's relaxed envelope requirements.

\section{Conclusion}

Although the 2006 IECC is less stringent than the 2003 code for buildings with high WWR, the evidence suggests that there are more buildings with sufficiently low WWR that the 2006 code, on average, is an improvement over the 2003 IECC. Further, based on available studies, survey data, and an understanding of building costs, there does not appear to be a measurable tendency for builders to use more glazing area under the 2006 IECC than under the 2003 IECC.

It is worth noting that the concept of having envelope component requirements that are independent of WWR is not unique to the 2006 IECC. A similar relationship exists in the 2003 IECC between solar heat gain coefficient (SHGC) requirements and the WWR.

The 2003 IECC requires a maximum 0.40 SHGC in the southern U.S. for all residential buildings without regard to WWR. Solar heat gain is a much more important energy efficiency characteristic of glazing than is U-factor in cooling-dominated climates. The 2006 IECC format change extended a similar independence to envelope thermal transmittance (U-factor) requirements. This is more important in heating-dominated climates, where the 2006 IECC appears to have more stringent average wall requirements than the 2003 IECC as discussed above.

The 2006 IECC has strong window requirements for all residential buildings - both lowand high-WWR. In fact, in heating-dominated climates (climate zones 5-8), the 2006 IECC has identical U-factor requirements to those in the Energy Star Windows program

\footnotetext{
${ }^{16}$ A quote from a study of new construction in California (PG\&E 2001): "Homes with large glazing percentages, especially glazing percentages exceeding the maximum prescriptive value of $20 \%$, tend to be non-compliant."
} 
that was current in 2006, including for buildings with high WWR. In cooling-dominated climates, where solar gains are more important than U-factors, the 2006 IECC has an identical SHGC requirement to that of both Energy Star and the 2003 IECC for all buildings, including those with high WWR. Conversely the 2003 IECC can have very lenient requirements for buildings with low WWR. The 2003 IECC also has much more lenient wall requirements for multifamily buildings than for single-family buildings (as evident on Figure 502.2(1) in the 2003 IECC), whereas the 2006 IECC has identical requirements for all residential buildings.

We conclude that the 2006 change in the format of the envelope requirements in the IECC will not reduce energy efficiency and may modestly improve energy efficiency on average. The window requirements in the 2006 IECC are as good or better than those in the 2003 IECC for a majority of building. 
